American Journal of Animal and Veterinary Sciences 4 (4): 92-94, 2009

ISSN 1557-4555

(C) 2009 Science Publications

\title{
Characterization of Bovine Calpastatin Gene in Nelore Cattle Using Polymerase Chain Reaction-Restricted Fragment Length Polymorphisms
}

\author{
${ }^{1,4}$ Alireza Majidi, ${ }^{1,2}$ Jothi Malar Panandam, ${ }^{1}$ Awis Qurni Sazili and ${ }^{3}$ Siti Shapor Siraj \\ ${ }^{1}$ Department of Animal Science, Faculty of Agriculture, \\ ${ }^{2}$ Department of Animal Science, Institute of Tropical Agriculture, \\ ${ }^{3}$ Department of Aquaculture, Faculty of Agriculture, \\ University Putra Malaysia, 43400 UPM Serdang, Selangor, Malaysia \\ ${ }^{4}$ Department of Animal Science, Agriculture Research Institute, Markazi Province, Iran
}

\begin{abstract}
Problem statement: In beef cattle production, of meat quality and carcass traits are important. Traditionally beef cattle breeding programs unfortunately are time consuming and also recording of carcass and growth traits need heavy cost, Approach: Marker Assisted Selection (MAS) should be utilized in beef herds, along with economically important phenotypic traits, for genetic progress to made with respect to improving the uniformity and consistency of beef. Blood samples were collected from 41 nelor cattle in Malaysia. Forward and reversed primers amplified a $1552 \mathrm{bp}$ fragment from calpastatin gene. XmnI enzyme was used for restriction analysis of PCR products. Result: Overall, the frequency of alleles A and B in the studied breeds were estimated as 0.42 and 0.58 , respectively. In this study we calculated genotype frequency $\mathrm{AA}, \mathrm{AB}$ and $\mathrm{BB} 12.2,58.53$ and $29.27 \%$ respectively and also observed heterozygosity, expected heterozygosity and average value of heterozygosity were $0.58,0.49$ and 0.48 respectively. Highest frequency of allele was B (0.58) and lowest was A (0.42) This Nelor cattle population was in the Hardy-Weinberg equilibrium. Conclusion: Perhaps, this molecular genetic information helps breeders for designing the proper genetic selection program in the development direction of this breed.
\end{abstract}

Key words: Bovine, calpastatin, polymerase, polymorphisms

\section{INTRODUCTION}

In Malaysia, there is an increasing preference by meat consumers for high quality and tender meat. It is clear that genetic background of the slaughtered animals makes a significant contribution to the variation in meat tenderness as tenderness varies among and within breeds.

Recently, genetic tests for meat tenderness in beef, utilizing genetic polymorphisms in the Calpastatin(CAST) and/or Calpain gene, have been made available by many private companies. The Calpain/calpastatin system is an endogenous, calciumdependent proteinase system, theorized to mediate the proteolysis of key myofibrillar proteins during postmortem storage of carcass and meat cuts at refrigerated temperatures ${ }^{[3]}$. Calpain is responsible for the breakdown of myofibril proteins, which are closely related to meat tenderness ${ }^{[11]}$. Calpastatin (CAST) inhibits $\mu$ and m-Calpain activity and, therefore, regulates postmortem proteolysis. Increased postmortem CAST activity has been correlated with reduced meat tenderness ${ }^{[3,8]}$. The CAST gene, mapped to BTA $7^{[1]}$, is considered a candidate gene for beef tenderness. The Nelore cattle is considered as a breed for economic beef production in the tropics and makes up $65 \%$ of the world's bovine population. The Nelore can efficiently convert poor quality forages into beef and withstand long periods without water. Due to their habit of feeding lightly but frequently, Nelore and Nelore hybrid cattle are highly resistant to bloating, which is a cause of death in other breeds. Excellent feed conversion ratio and good disposition allows the Nelore to be early finished in feedlots, with highly positive results ${ }^{[6]}$. Currently, Malaysia imported large number of this cattle breed from Brazil due to their high adaptation and productivity.

The objective of this study was to assess the allelic variation at the bovine calpastatin gene in the Nelore cattle in Malaysia using PCR-RFLP.

Corresponding Author: Jothi Malar Panandam, Department of Animal Science, Faculty of Agriculture, University Putra Malaysia, 43400 UPM Serdang, Selangor, Malaysia 


\section{MATERIALS AND METHODS}

DNA was extracted from the blood of 41 animals from the Nelore herd of the Department of veterinary services Malaysia. The DNA was amplified with primers for calpastatin gene Chung et al. ${ }^{[2]}$ :

Forward primer: 5- AGCAGCCACCATCAGAGAAA-3 Reverse primer: 5-TCAGCTGGTTCGGCAGAT-3

For amplification of calpastatin gene region among the Intron 6, DNA solution (100 ng) was added to $25 \mu \mathrm{L}$ PCR mix. The PCR mix contained: $2.5 \mu \mathrm{L}$ PCR buffer $\left(670 \mathrm{mM}\right.$ Tris- $\mathrm{HCl} \mathrm{pH} 8.8,160 \mathrm{mM}(\mathrm{NH} 4)_{2} \mathrm{SO}_{4}$, $0.1 \% \mathrm{mM}$ Tween 20), $1 \mu \mathrm{L} \mathrm{MgCl}_{2}$, dNTP, $0.1 \mu \mathrm{g}$ of each primer), $2 \mathrm{U}$ Taq DNA polymerase and $\mathrm{ddH}_{2} \mathrm{O}$.

Samples were amplified for 35 cycles (Thermocycle MJ Research PTC-200) with the following regime: denaturation step at $95^{\circ} \mathrm{C}$ for $1 \mathrm{~min}$, annealing at $65^{\circ} \mathrm{C}$ for $30 \mathrm{sec}$ and extension step at $74^{\circ} \mathrm{C}$ for $40 \mathrm{sec}$.

Products of amplification were checked by electrophoresis in $1 \%$ agarose gel. The gel stained with ethidium bromide and viewed under UV light.

PCR-RFLP: The PCR products were digested by $\mathrm{XmnI}$ the restriction endonuclease. Digestion was conducted at $37^{\circ} \mathrm{C}$ for $24 \mathrm{~h}$ and in a $10 \mu \mathrm{L}$ reaction solution contains $2.7 \mu \mathrm{L}$ distilled $\mathrm{H}_{2} \mathrm{O}, 1.0 \mu \mathrm{L}$ of specific Buffer, $0.3 \mu \mathrm{L} \quad(3 \mathrm{U})$ of restriction endonuclease and $6 \mu \mathrm{L}$ of PCR product solution. The DNA fragments from the digested PCR products were separated $2.0 \%$ electrophoresis agarose gel containing in ethidium bromide $\left(0.4 \mu \mathrm{g} \mathrm{mL}^{-1}\right)$. Electrophoresis was performed in $1 \times$ TBE buffer $(108 \mathrm{~g}$ Tris, $55 \mathrm{~g}$ boric acid and $40 \mathrm{~mL}$ of $0.5 \mathrm{M}$ EDTA in $1,000 \mathrm{~mL}$ of $10 \times$ concentrated stock solution, $\mathrm{pH}$ 8.0) under $120 \mathrm{~V}$ for $45 \mathrm{~min}$.

\section{RESULTS}

Three genotypes were observed in this population and these are shown in Fig. 1. Two alleles were observed. The frequency of alleles $\mathrm{A}$ and $\mathrm{B}$ in the population were 0.42 and 0.58 , respectively. The genotypic frequencies of $\mathrm{AA}, \mathrm{AB}$ and $\mathrm{BB}$ were 0.122 , 0.585 and 0.293 , respectively. Observed, expected heterozygosities were $0.58,0.49$ and 0.48 , respectively. The Nelore population was in Hardy-Weinberg equilibrium for the locus $(p>0.05)$. The information generated from this study may be utilized in designing selection program for this breed.

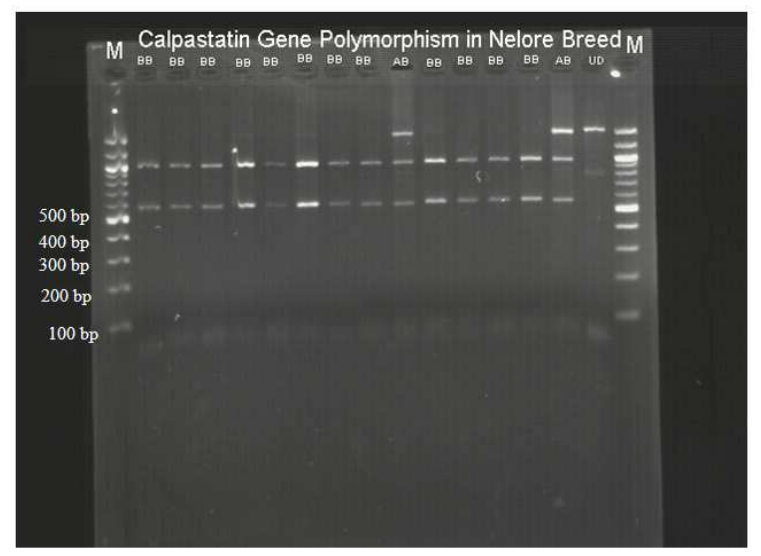

Fig. 1: The three genotype at calpastatin gene in the Nelore population. M: $100 \mathrm{bp}$ DNA size ladder

\section{DISCUSSION}

Shackelford et al. ${ }^{[10]}$ showed that approximately $65 \%$ of the variation in tenderness among cattle of all breeds was due to genetic effects. In an experiment with Angus bulls Palmer et al. ${ }^{[7]}$ observed three genotypes and two alleles for CASTI and CAST5 loci and six genotypes $\mathrm{AA}, \mathrm{BB}, \mathrm{CC}, \mathrm{AB}, \mathrm{AC}$ and $\mathrm{BC}$, for CAST10 locus. Single Nucleotide Polymorphisms (SNPs) in the calpastatin (CAST) gene was studied in Bos taurus (Jersey $\times$ Limousin, Angus and Hereford-cross cattle) by Morris et al. ${ }^{[5]}$. Schenkel et al. ${ }^{[9]}$ identified a SNP in the CAST gene ( $\mathrm{G}$ to $\mathrm{C}$ substitution) in the crossbred commercial heifers, steers and bulls from the beef feedlots of the University of Guelph. They identified three genotypes (CC, CG and GG) and reported that the CAST's SNP allele C was more frequent (63\%) than Gallele. Kurly et al. ${ }^{[4]}$ identified the polymorphism of Calpastatin gene with three restriction enzymes (Hinf I, MspI, RsaI) in Stambeek (Dutch Large whitex Dutch Landrrace) pig breed.

\section{CONCLUSION}

The results of this study showed that the frequency of allele B was higher than frequency of $\mathrm{A}$ in the Nelore population. This Nelor cattle population was in the Hardy-Weinberg equilibrium. This molecular genetic information may be used by breeders for designing the genetic selection program for the development of this breed.

\section{ACKNOWLEDGMENT}

The researchers would like to express their deep appreciation to the Department of Veterinary Services 
Malaysia for their support of this project. We thank the management and staff of farm for their assistance in sampling of animals.

\section{REFERNCES}

1. Bishop, M.D., M. Koohmaraie, J. Killefer and S. Kappes, 1993. Rapid communication: Restriction fragment length polymorphisms in the bovine calpastatin gene. J. Anim. Sci., 71: 2277-2277.

2. Chung, H. Y. Davis, H. C and Hins, H. C, 2001. Genetic variation detected by PCR-RFLP in intron 6 of the bovine calpastatin gene. Anim. Genet., 32: 40-53.

3. Koohmaraie, M., 1994. Muscle proteinases and meat aging. Meat Sci., 36: 93-104.

4. Kurly, J., W. Kapelanski and M. Pierzchala, 2002. Preliminary observations on the effect of Calpastatin gene polytmorphism in carcass trait in pigs. Anim. Sci. Paper Rep., 2: 87-95.

5. Morris, C.A., N.G. Cullen, S.M. Hickey, P.M. Dobbie and B.A. Veenvliet et al., 2006. Genotypic effects of calpain 1 and calpastatin on the tenderness of cooked M. longissimus dorsi steaks from Jersey Limousin, angus hereford-cross cattle. Anim. Gene., 37: 411-414.

6. Mason, I.L., 1988. World Dictionary of Livestock Breeds. 3rd Edn., CAB International. Wallingford, Oxon. OX10 8DE, U.K., pp: 348.
7. Palmer, B.R., J.D. Morton and N. Roberts, 1999. Marker-assisted selection for meat quality and the ovine calpastatin gene. Proc. N. Z. Soc. Anim. Prod., 59: 266-268.

8. Pringle, T.D., S.E. Williams, B.S. Lamb, D.D. Johnson and R.L. West, 1997. Carcass characteristics, the Calpain proteinase system and aged tenderness of Angus and Brahman crossbred steers. J. Anim. Sci., 75: 2955-2961.

9 Schenkel, F.S., S.P. Miller, Z. Jiang, I.B. Mandell, X. Ye, H. Li and J.W. Wilton, 2006. Association of a single nucleotide polymorphism in the calpastatin gene with carcass and meat quality traits of beef cattle. Anim. Sci., 84: 291-299.

10. Shackelford, S.D., M. Koohmaraie, L.V. Cundiff, K.E. Gregory, G.A. Rohrer and J.W. Savell, 1994. Heritability and phenotypic and genetic correlations for bovine postrigor calpastatin activity, intramuscular fat content, Warner Bratzler Shear force, retail product yield and growth rate. J. Anim. Sci., 72: 857-863.

11. Wheeler, T.L. and M. Koohmaraie, 1994. Prerigor and postrigor changes in tenderness of ovine longissimus muscle. J. Anim. Sci., 72: 1232-1338. 